\title{
ASESMEN IMPLEMENTASI KEBIJAKAN KARTU IDENTITAS ANAK SEBAGAI PEMENUHAN HAK ANAK
}

\section{Khaerul Umam Noer}

Program Pascasarjana Ilmu Administrasi Universitas Muhammadiyah Jakarta

Email: umam.noer@umj.ac.id

\section{Abstract}

Since 2015, the Mayor of Depok has issued an order for the issuance of Child Identity Cards (CIC) as part of fulfilling children's basic rights. This policy is important because Law 35/2014 has mandated that the state must ensure the fulfillment of children's basic rights and needs through Child Friendly Cities as a child rights-based development system by integrating commitments and resources from the government, society and the business sector. After five years, the CIC program in Depok has stagnated, both in terms of implementation and outcomes. This paper aims to assess the implementation of the Child Identity Card policy with a focus on two questions: First, how the Depok City Government ensures the implementation of the policy, Second, due the CIC is cross-sectoral, then how can the government collaborate with stakeholders to make this policy a success. By using a descriptive qualitative method, this study found that there were three obstacles to implementing CIC: bureaucracy, limited resources, and communication problems that caused data collection and publication of CIC to be an unsolved problem.

Keywords: child identity card; child rights and protection; policy implementation; depok

\section{Abstrak}

Sejak 2015, Wali Kota Depok telah mengeluarkan perintah untuk penerbitan Kartu Identitas Anak sebagai bagian dari pemenuhan hak dasar anak. Kebijakan ini penting sebab UU 35/2014 telah mengamanatkan bahwa negara harus menjamin terpenuhinya hak dan kebutuhan dasar anak melalui Kota Layak Anak (KLA) sebagai sistem pembangunan berbasis hak anak dengan mengintegrasikan komitmen dan sumber daya dari pemerintah, masyarakat dan sektor bisnis. Persoalannya adalah, setelah lima tahun, program KIA di Depok mengalami stagnasi, baik dalam pelaksanaan maupun hasil luaran. Tulisan ini bertujuan untuk melakukan penilaian terhadap implementasi kebijakan Kartu Identitas Anak dengan fokus pada dua hal: Pertama, bagaimana Pemerintah Kota Depok memastikan pelaksanaan kebijakan, Kedua, karena KIA bersifat lintas sector, maka bagaimana pemerintah menggandeng para pemangku kepentingan untuk mensukseskan kebijakan ini. Dengan menggunakan metode kualitatif deskriptif, penelitian ini menemukan bahwa ada tiga hambatan untuk menerapkan KIA: birokrasi, sumber

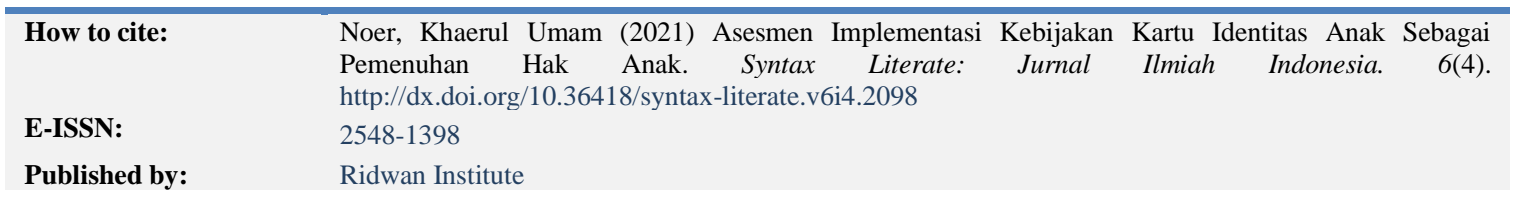


daya yang terbatas, dan masalah komunikasi yang menyebabkan pengumpulan data dan penerbitan KIA menjadi problem yang tidak terselesaikan hingga hari ini.

Kata Kunci: kartu identitas anak; hak dan perlindungan anak; implementasi kebijakan; depok

\section{Pendahuluan}

Sejak tahun 1990, Pemerintah Indonesia telah meratifikasi Konvensi Hak Anak (Noer, 2019; Patilima, 2017), yang diadopsi dari Majelis Umum PBB tahun 1989, menjelaskan bahwa setiap anak tanpa memandang ras, jenis kelamin, asal usul keturunan, agama maupun bahasa, mempunyai hak hak yang mencakup empat bidang, yaitu: (1) hak atas kelangsungan hidup, menyangkut hak atas tingkat hidup yang layak dan pelayanan kesehatan; (2) hak untuk berkembang, mencakup hak atas pendidikan, informasi, waktu luang, kegiatan seni dan budaya, kebebasan berpikir, berkeyakinan, dan beragama, serta hak anak berkebutuhan khusus; (3) hak perlindungan, mencakup perlindungan atas segala bentuk eksploitasi, perlakuan kejam dan sewenang-wenang dalam proses peradilan pidana; dan (4) hak partisipasi, meliputi kebebasan untuk menyatakan pendapat, berkumpul dan berserikat, serta hak untuk ikut serta da lam pengambilan keputusan yang menyangkut dirinya.

Ratifikasi ini kemudian diturunkan menjadi UU 23/2002, yang kemudian direvisi menjadi UU 35/2014 Tentang Perlindungan Anak. Konstitusi dan UU mengamanatkan bahwa Negara harus menjamin pemenuhan hak dan kebutuhan dasar anak, sehingga anak dapat tumbuh dan berkembang secara sehat dan wajar. UU 35/2014 mengisyaratkan pentingnya pemerintah Kabupaten/Kota di Indonesia untuk menjadi Kota Layak Anak (selanjutnya disingkat KLA). KLA adalah Kabupaten/Kota yang mempunyai sistem pembangunan berbasis hak anak melalui pengintegrasian komitmen dan sumber daya pemerintah, masyarakat dan dunia usaha, yang terencana secara menyeluruh dan berkelanjutan dalam kebijakan, program dan kegiatan untuk menjamin terpenuhinya hak dan perlindungan anak.

Sesuai dengan amanat UU Perlindungan Anak, Pemerintah Kota Depok terus meningkatkan berbagai upaya dalam mewujudkan salah satu program andalannya yaitu Depok sebagai KLA. Maka sejak tahun 2015, melalui Peraturan Wali Kota Nomor 35/2015, Pemerintah Kota Depok mendorong hadirnya Kartu Identitas Anak (selanjutnya disingkat KIA) sebagai bagian dari pemenuhan hak dasar anak, utamanya hak atas pengakuan kependudukan. Hal tersebut dilakukan guna memberikan kesadaran akan pentingnya hak-hak yang harus diterima seorang anak dan berbagai kewajiban yang harus dipenuhi terhadap anak. KIA berfungsi sebagai Kartu Identitas Diri dan fasilitas kepada anak berupa keringanan pembayaran terhadap fasilitas yang diberikan oleh pihak pemangku kepentingan.

Tulisan ini berfokus pada bagaimana implementasi Peraturan Wali Kota 35/2015 Tentang Kartu Identitas Anak. Secara khusus, tulisan ini berfokus pada dua hal: (a) bagaimana implementasi KIA oleh Dinas Kependudukan dan Pencatatan Sipil, dan (b) karena KIA bersifat lintas sektor, bagaimana Pemerintah Kota Depok menggandeng 
pemangku kepentingan, mulai dari perbankan, vendor fasilitas olahraga, toko buku, dan fasilitas kesehatan, untuk terlibat dalam KIA dalam upaya Depok sebagai Kota Layak Anak. Hal ini menarik untuk dilakukan, seperti yang dikemukakan oleh Meru, kebijakan KIA muncul sebagai respon pemerintah Kota Depok atas UU 35/2014 (Meru, 2017), sedangkan KIA sendiri adalah salah satu indikator yang digunakan oleh Pemerintah Depok untuk menyatakan klaimnya bahwa Depok adalah Kota Layak Anak (Widyawati \& Laksmitasari, 2015). Penelitian ini mencoba melakukan sejumlah asesmen, apakah klaim Depok sebagai Kota Layak Anak benar dilakukan, dengan berfokus pada satu hal: Kartu Identitas Anak.

Pada dasarnya, Kota Layak Anak sebagai suatu program memiliki banyak indikator yang sudah cukup banyak dikaji dari berbagai sudut pandang. Dimulai dari proses pembuatan KLA sebagai kebijakan di berbagai daerah dan berbagai prasyarat yang dibutuhkan oleh daerah-daerah tersebut (Adnyani, 2019; Haifulloh, Purnomo, \& Salsabila, 2020; Irenes \& Setiamandani, 2019; Taliu \& Suranto, 2020; Taufiq, Hadikurniawati, Muhammadiyah, \& Informatika, 2019), bagaimana implementasi KLA dilakukan oleh berbagai dinas dan bidang pelaksana di berbagai pemerintah daerah (Hamudy, 2015; Noer, 2019; Roza \& S, 2018; Widyawati \& Laksmitasari, 2015), ketersediaan Ruang Publik Terpadu Ramah Anak sebagai ruang publik yang dapat diakses oleh semua anak (Faedlulloh, Prasetyanti, \& Indrawati, 2017; Herlina \& Nadiroh, 2018; Hernowo \& Navastara, 2017), dan peran serta tanggung jawab pemerintah dalam mengatasi pelanggaran hak-hak anak (Fitriani, 2016; Putri \& Noor, 2013).

Sementara itu, kajian mengenai KIA lebih banyak berfokus pada tiga hal. Pertama, kajian-kajian yang berfokus pada aspek hukum dalam pelayanan sektor publik dalam implementasi KIA, dalam hal ini KIA dilihat sebagai program yang memiliki payung hukum yang harus dilaksanakan oleh pemerintah di daerah (Setiawan, 2017; Simamora, Bahmid, \& Martua, 2019; Yudha \& Firdausi, 2017), atau KIA sebagai hasil advokasi kebijakan dalam rangka pemenuhan hak sipil dan legal anak (Sri Hardjanto, 2019). Kedua, kajian mengenai KIA yang berfokus pada implementasi Peraturan Menteri Dalam Negeri Nomor 2/2016 dalam implemetasi KIA di daerah (Adnyani, 2019; Iswariayti, Parsa, \& Suardita, 2016). Ketiga, kajian mengenai implementasi KIA secara birokratis yang dilakukan oleh Dinas Kependudukan dan Pencatatan Sipil di berbagai wilayah (Arista \& Suderana, 2019; Meru, 2017; Pasaribu, 2018; Putri \& Noor, 2013).

Berbagai penelitian di atas, meski berfokus pada implementasi tidak melihat dua hal pokok: bagaimana hambatan dalam implementasi dan bagaimana kerjasama lintas bidang dalam pelaksanaan KIA di lapangan. Penelitian ini secara spesifik mengisi kekosongan kajian-kajian yang ada dengan berfokus pada hambatan yang muncul dalam proses implementasi KIA dan bagaimana kerjasama lintas bidang, bukan hanya Dinas Kependudukan dan Pencatatan Sipil, dalam implementasi KIA di Kota Depok. Implementasi secara sederhana merupakan suatu kegiatan atau usaha yang dilakukan oleh pelaksana kebijakan dengan harapan akan memperoleh suatu hasil yang sesuai 
dengan tujuan atau sasaran dari suatu kebijakan. Dengan menitikberatkan pada persoalan implementasi, tulisan ini berfokus pada upaya sekaligus memetakan kendala yang dihadapi sekaligus potensi solusi oleh Pemerintah Kota Depok dalam pelaksanaan program KIA. Hal ini menarik sekaligus krusial untuk dikaji, sebab Kementerian Pemberdayaan Perempuan dan Perlindungan Anak Republik Indonesia telah mewajibkan KIA sebagai salah satu indikator utama Kota Layak Anak, dan Depok menjadi salah satu pilot project Kota Layak Anak di Jawa Barat. Penelitian ini diharapkan mampu memberikan sumbangan rekomendasi dalam upaya implementasi KIA sebagai pemenuhan hak dasar anak sekaligus mendorong percepatan Kota Depok sebagai Kota Layak Anak di Indonesia

\section{Metode Penelitian}

Penelitian ini menggunakan metode penelitian kualitatif dengan pendekatan deskriptif. Penelitian dilakukan di Dinas Kependudukan dan Catatan Sipil Kota Depok, Dinas Pendidikan Kota Depok, Mitra KIA antara lain perbankan, penyedia fasilitas olahraga dan rekreasi, fasilitas kesehatan, dan toko buku. Terdapat dua puluh enam informan yang menjadi sumber informasi dalam penelitian ini, mencakup Kepala Dinas Kependudukan dan Catatan Sipil, Kepala Bidang Kependudukan, tiga orang operator KIA di kecamatan, Kepala Dinas Pendidikan, empat orang kepala sekolah, empat orang komite sekolah, empat orang pelajar, manajer operasional bank, manajer operasional toko, dan manajer operasional wahana tirta, dan empat orang masyarakat yang sedang mengurus KIA di kecamatan. Selain wawancara, pengamatan partisipatif juga dilakukan dengan mengunjungi berbagai kelurahan untuk mengamati langsung bagaimana proses perekaman data KIA, dan pengamatan ke Mitra KIA, antara toko buku dan sarana olahraga dan rekreasi untuk mengamati bagaimana penggunaan KIA oleh pemegang kartu KIA.

Selain wawancara dan pengamatan, peneliti juga mengumpulkan berbagai data dokumen, seperti perjanjian kerjasama antara Dinas Kependudukan dan Pencatatan Sipil Kota Depok dengan para Mitra KIA, dokumentasi kegiatan, dan regulasi terkait KIA. Data-data ini kemudian disusun menjadi sejumlah kode untuk kemudian dianalisis. Melalui teknik trianggulasi, peneliti melakukan pengecekan silang data yang diperoleh dari informan satu dengan informan lainnya serta membandingkan data hasil wawancara dengan hasil pengamatan berkaitan dengan pelaksanaan penerbitan dan pemberian KIA di Kota Depok. Dengan teknik ini, penelitian mengenai KIA diharapkan mampu memberikan gambaran yang seakurat mungkin untuk menjelaskan bagaimana KIA dilaksanakan dan kendala yang dihadapi dalam pelaksanaan di lapangan.

\section{Hasil dan Pembahasan}

\section{A. Kebijakan Kartu Identitas Anak}

Dalam rangka pemenuhan salah satu hak sipil anak dan untuk mewujudkan Depok sebagai Kota Layak Anak sesuai ketentuan dalam Pasal 16 ayat (1) huruf F Peraturan Daerah Kota Depok Nomor 15 Tahun 2013 Tentang Kota Layak Anak, 
Pemerintah Kota Depok memberikan Kartu Identitas Anak (KIA) sampai dengan usia 17 tahun. Untuk melaksanakan tugas tersebut, maka Dinas Kependudukan dan Pencatatan Sipil (selanjutnya disebut Disdukcapil) adalah Organisasi Perangkat Daerah yang bertanggungjawab penuh dalam implementasi KIA di lapangan.

Pelaksanaan Kartu Identitas Anak di Kota Depok merupakan kebijakan yang diimplememtasikan oleh Disdukcapil Kota Depok sebagai salah satu program untuk mendukung Depok Kota Layak Anak yang dimulai pada Tahun Anggaran Perubahan 2015. Ketika program ini mulai berjalan di tahun 2016, sebanyak 57.143 anak telah mendapatkan, dan hingga akhir 2019, sebanyak 140.578 anak yang telah mendapatkan KIA. Sepintas data ini menunjukkan bahwa terdapat progress signifikan dalam perekaman dan penerbitan data KIA, namun jika dihitung, selama periode 2017-2019, hanya terbit 83,435 KIA baru, atau rata-rata tercatat 27,811 KIA di Kota Depok setiap tahunnya. Hal ini menarik, sebab berdasarkan data jumlah anak di Kota Depok pada tahun 2019 mencapai 501,168 anak, masih tersisa 360,590 anak yang belum terekam dan mendapatkan KIA.

Pemberian KIA dimaksudkan untuk mendorong terpenuhinya hak sipil anak dan mendorong peningkatan kesejahteraan anak baik secara rohani, jasmani maupun sosial. Tujuan lain KIA adalah sebagai kartu yang memberikan fasilitasi kepada anak berupa keringanan pembayaran terhadap fasilitas yang diberikan oleh Mitra KIA berdasarkan kesepakatan bersama antara Pemerintah Kota Depok dengan Mitra. Adapun sasaran pemberian Kartu Identitas Anak ini adalah anak yang berdomisili dan terdaftar dalam Kartu Keluarga di Kota Depok yang berusia 1 (satu) tahun sampai dengan 17 (tujuh belas) tahun dan belum menikah. Dengan ruang lingkupnya meliputi pelayanan pendidikan, kesehatan, pariwisata, olah raga, perbankan dan fasilitas lain yang ditentukan oleh Walikota.

Kartu Identitas Anak diterbitkan oleh Disdukcapil Kota Depok dan ditanda tangani oleh Kepala Dinas dengan tidak dipungut biaya. Kepala Dinas melaksanakan koordinasi dan komunikasi dengan Mitra mulai dari tahap persiapan, sosialiasasi, penerbitan Kartu Identitas Anak sampai dengan pemanfaatan Kartu Identitas Anak. Sedangkan Mitra KIA sebagai pihak kedua dalam pemberian fasilitasi Kartu Identitas Anak wajib memberikan laporan penggunaan Kartu Identitas Anak secara periodik setiap 3 bulan sekali kepada Walikota.

Kebijakan Kartu Identitas Anak digagas dan dilaksanakan oleh Disdukcapil Kota Depok berdasarkan indikator Kota Layak Anak di Indonesia melalui perencanaan yang dilakukan dari tingkat bawah yaitu adanya kajian dan telaah staf dari Disdukcapil yang ditujukan kepada Walikota, karena Kartu Identitas Anak merupakan salah satu kebijakan untuk mewujudkan Kota Layak Anak di Kota Depok. Pemilihan kebijakan KIA ini merupakan urutan utama program lokal setelah program-program Nasional E-KTP dan Akta Kelahiran, karena dengan KIA diharapkan pemberian Akte Kelahiran anak di Kota Depok dapat terus ditingkatkan sesuai dengan target yang ada, karena pada tahun-tahun sebelumnya masih di bawah 
standar yaitu $20 \%$ dari target $75 \%$ dari seluruh jumlah anak yang ada di Kota Depok.

Selanjutnya disusunlah rencana organisasi sampai dengan tingkat pimpinan tertinggi, yaitu Walikota dan DPRD atas dasar rencana, kebutuhan, keinginan dan permasalahan yang dihadapi, untuk selanjutnya bersama-sama dengan atasan menetapkan kebijakan atau pengambilan keputusan dan atasan berfungsi sebagai fasilitator. Karena konsep ini membawa manfaat yang positif bagi anak-anak Kota Depok maka unsur pimpinan merespon dengan baik dan menyetujui menjadi suatu kebijakan lokal yang terus dikembangkan. Pada perjalanannya, pemerintah pusat menjadikan kebijakan KIA sebagai kebijakan nasional, yang dalam beberapa hal memiliki perbedaan dengan KIA yang diimplementasikan di Depok, maka Pemerintah Kota Depok melakukan sejumlah penyesuaian dengan KIA Nasional karena pada dasarnya antara KIA Kota Depok dan KIA Nasional mempunyai manfaat yang sama.

Hal ini menunjukkan bahwa dalam penyusunan kebijakan merupakan proses yang sangat strategis di mana ada ruang untuk memaknai masalah publik dan prioritas dalam agenda publik yang diutamakan demi kepentingan masyarakat. Sejalan dengan proses perencanaan dalam Peraturan Walikota Depok Tentang Kartu Identitas Anak di Kota Depok bahwa terus berupaya meningkatkan pelayanan administrasi kependudukan kepada masyarakat, khususnya anak-anak di Kota Depok untuk mendukung program Kota Layak Anak di Kota Depok yang telah dirintis sejak tahun 2011.

Adapun indikator Kota Layak Anak sesuai dengan Peraturan Daerah Kota Depok Nomor 15/2013 Tentang Penyelenggaraan Kota Layak Anak adalah variabel sebagai ukuran dan nilai dari kenerja tahunan di dalam pemenuhan hak anak yang wajib dicapai melalui kebijakan, program, kegiatan dan penanganan untuk mewujudkan Kota Layak Anak. Dijelaskan bahwa indikator Kota Layak Anak yang dimaksud dalam Peraturan Daerah tersebut merupakan turunan dan sesuai dengan indikator yang tercantum dalam Peraturan Menteri Pemberdayaan Perempuan dan Perlindungan Anak Nomor 12/2011. Dalam hal ini Pemerintah Kota Depok masih terdapat beberapa permasalahan yang muncul karena adanya indikator dari Kota Layak Anak yang belum terpenuhi terutama yang berkaitan dengan pelaksanaan KIA sehingga Disdukcapil harus terus meningkatkan kinerjanya dan menguatkan sisi kelembagaan dan program, untuk mencapai tujuan dan sasaran yang tepat dalam pelaksanaan KIA di Kota Depok

\section{B. Persoalan Birokrasi dan Sumberdaya}

Salah satu titik krusial persoalan KIA terletak pada internal Disdukcapil, dalam hal ini terletak pada dua hal pokok: struktur birokrasi dan minimnya fasilitas pelaksana. Disdukcapil Kota Depok memiliki tiga tujuan utama, yaitu: (a) tertib administrasi kependudukan, (b) tertib administrasi pencatatan sipil, dan (c) berbasis teknologi informasi. Dalam mewujudkan tujuan tersebut, maka Disdukcapil membentuk sejumlah misi organisasi, antara lain: (a) meningkatkan profesionalisme 
SDM yang berorientasi pelayanan berkualitas dengan memberikan pelayanan secara ramah, akurat, cepat, dan transparan; (b) meningkatkan kualitas database kependudukan dan pencatatan sipil melalui pengelolaan databerbasis teknologi informasi; dan (c) meningkatkan kualitas pelayanan administrasi kependudukan dan pencatatan sipil melalui penyediaan pelayanan yang berkualitas untuk memenuhi kepuasan masyarakat. Persoalannya adalah, dengan ketika tujuan dan misi dilaksanakan di lapangan, masih sangat jauh dari harapan. Dilihat dari stuktur birokrasi, pelaksanaan KIA di lapangan memiliki prosedur operasi standar yang jelas, namun dalam pelaksanaannya, terdapat beberapa masalah yang tidak diatur dalam kebijakan KIA dan/atau masalah yang muncul karena pengaturan birokrasi yang tidak mempertimbangkan aspek sosiokultural untuk memperoleh KIA.

Secara umum, persyaratan penerbitan KIA baru adalah: (a) mengisi formulir permohonan Kartu Identitas Anak; (b) fotocopi Akta Kelahiran anak; (c) pas photo anak berwarna ukuran $2 \times 3$ sebanyak 2 lembar bagi anak usia 1 (satu) tahun sampai dengan 5 (lima) tahun; (d) rekam photo anak bagi anak usia diatas 5 tahun, dan (e) fotocopi Kartu Keluarga. Kartu Identitas Anak berlaku bagi semua anak yang ada di Kota Depok tanpa terkecuali. Adapun persyaratan Kartu Identitas Anak yang hilang/rusak yaitu: (a) surat keterangan kehilangan dari kepolisian bagi Kartu Identitas Anak yang hilang, (b) Kartu Identitas Anak yang asli bagi yang rusak; (c) pas poto anak berwarna ukuran $2 \times 3$ sebanyak 2 lembar bagi anak usia 1 (satu) tahun sampai dengan 5 tahun, dan (d) fotocopi Kartu Keluarga orang tua. Persyaratan penerbitan Kartu Identitas Anak yang habis masa berlakunya adalah sebagai berikut: (a) Kartu Identitas Anak Asli; (b) pas photo anak berwarna ukuran 2x3 sebanyak 2 lembar bagi anak usia 1 sampai dengan 5 tahun, dan (c) foto copy Kartu Keluarga orang tua.

Jika dilihat sepintas, tidak ada masalah dalam penerbitan KIA, namun di lapangan, hal yang justru muncul adalah penolakan dalam perekaman. Secara umum, terdapat dua kelompok yang tidak dapat mengajukan perekaman KIA. Kelompok pertama adalah mereka yang tidak dapat mengajukan KIA karena merupakan anak-anak yang lahir dari perkawinan yang tidak dicatatkan. Tidak ada catatan resmi mengenai jumlah perkawinan yang tidak dicatatkan di Depok, meski demikian, hingga medio 2019 tercatat empat belas permohonan KIA yang ditangguhkan karena persoalan ini. Salah satu titik solusi sebetulnya ada pernah dimunculkan melalui Peraturan Menteri Dalam Negeri 9/2016, Pasal 3 Ayat 2 mengenai pencatatan anak yang tidak diketahui asal usulnya atau keberadaan orang tuanya dilakukan dengan: a. Melampirkan Berita Acara Pemeriksaan (BAP) dari Kepolisian atau b. Menggunakan Surat Pertanggungjawaban Mutlak (SPTJM) kebenaran data kelahiran yang ditandatangani oleh wali/penanggungjawab. Kartu Identitas Anak dapat diperoleh setelah mengurus Akta Kelahiran di Kota Depok tanpa menyertakan identitas dari pihak ayah dan yang tertera di Akta Kelahiran adalah nama ibu. 
Meski secara aturan jelas bagaimana KIA dapat diajukan untuk anak yang lahir dari pernikahan yang tidak dicatatkan, baik melalui perkawinan sirri atau kelahiran tanpa ayah, namun secara faktual hal ini tidak semudah yang dibayangkan. Dalam wawancara dengan keluarga yang pengajuan KIA anaknya ditolak, yang muncul adalah Surat Pertanggungjawaban Mutlak yang mereka buat ditolak oleh Disdukcapil, karena Disdukcapil merujuk pada poin A, yakni hanya menerima Berita Acara Pemeriksaan dari kepolisian. Persoalannya adalah, tidak semua orang memiliki keberanian untuk ke kantor polisi dan mengajukan BAP untuk menjelaskan status perkawinan mereka yang tidak dicatatkan. Beberapa orang yang diwawancara menjelaskan bahwa polisi menolak BAP mereka karena mereka tidak dapat membuktikan bahwa mereka telah melalukan perkawinan meski tidak dicatatkan, salah satu pembuktian yang harus mereka hadirkan adalah saksi-saksi dari pihak keluarga. Hal ini tentu saja menyulitkan bagi mereka yang menikah ketika mereka berada di luar negeri sebagai buruh migrant, di mana saksi mereka adalah teman-teman mereka sendiri, atau ketika saksi-saksi yang ada telah meninggal dunia. Tidak dicatatkannya perkawinan mereka membawa konsekuensi serius, bahwa anak-anak yang lahir tidak dapat memperoleh Akta Kelahiran, padahal Akta Kelahiran adalah prasyarat utama KIA.

Kelompok kedua mereka yang tidak mendapatkan KIA adalah anak-anak yang kelahirannya tidak dapat dibuktikan melalui Akta Kelahiran. Meski terdengar absurd, kondisi ini banyak muncul di lapangan. Persoalannya terletak pada aturan untuk dikeluarkannya Akta Kelahiran oleh Pemerintah Kota Depok. Terdapat tiga syarat yang harus dipenuhi untuk dikeluarkannya Akta Kelahiran: (a) salinan surat nikah kedua orangtua yang dilegalisir, (b) surat asli dari bidan dan/atau dokter, dan (c) keharusan untuk menghadirkan dua orang saksi, lengkap dengan salinan kartu identitasnya. Kondisi ini jelas sangat menyulitkan bagi orangtua miskin yang karena keterbatasan biaya memilih untuk melahirkan di rumah dengan bantuan dari dukun beranak, hal mana sangat dilarang oleh Dinas Kesehatan Kota Depok. Dengan lahir di rumah, tanpa bantuan dari tenaga medis, baik bidan dan dokter, maka tidak mungkin ada surat keterangan, yang membuat mustahil dikeluarkannya Akta Kelahiran, meskipun pasangan suami istri tersebut mencatatkan perkawinan mereka. Kondisi lainnya adalah ketiadaan saksi, apalagi dituntut saksi untuk memberikan identitas pribadinya, yang secara legal menyatakan bahwa proses kelahiran tersebut benar adanya.

Dengan demikian, kendala implementasi KIA di tingkat Disdukcapil bukan karena tidakjelasnya standar operasional prosedur, namun karena standar itu sendiri begitu ideal sehingga sulit tercapai ketika dilaksanakan di lapangan. Kesulitannya tidak hanya dalam memenuhi syarat-syarat yang ditentukan oleh kebijakan, baik itu Akta Kelahiran, KIA, dan EKTP, namun juga dalam prosesnya, perekaman data hingga pencetakan kartu, baik KIA maupun EKTP membutuhkan waktu yang sangat panjang. Panjangnya waktu yang dibutuhkan adalah sisi lain dari persoalan di tingkat pelaksana: keterbatasan sumber daya. 
Secara umum, sumber daya dapat dilihat dari dua sisi: dari sisi manusia dan infrastruktur. Dari sisi manusia, staf dalam hal ini adalah operator SIAK, adalah titik krusial. Keberadaannya tidak sesuai dengan jumlah dan kemampuan yang ditargetkan. Seluruh operator SIAK diharuskan untuk merekam E-KTP dan KIA. Model sentralistik untuk seluruh data kependudukan, ditambah dengan sangat variatifnya data yang dihasilkan, ditambah pula dengan terbatasnya personalia yang ada, baik di tingkat kelurahan, kecamatan dan kota, menyebabkan proses pendataan, perekaman, dan pencetakan KIA menjadi terhambat.

Di tingkat pelaksaan program KIA misalnya, jumlah operator di setiap kelurahan hanya satu orang, dengan kemampuan khusus sebagai operator SIAK yang telah mendapatkan bimbingan teknis beberapa kali dan sertifikat keahlian sehingga memiliki kemampuan dalam pelayanan administrasi kependudukan. Namun jumlah operator di setiap kelurahan sangat kurang karena tidak sebanding dengan pelayanan dan jumlah penduduk di masing-masing kelurahan. Hal ini menyebabkan manakala operator berhalangan hadir maka pelayanan akan terhenti, idealnya dalam satu kelurahan ada dua operator, sehingga tidak ada pelayanan adaministrasi yang tertunda seperti yang dikeluhkan oleh masyarakat sebagai Informan bahwa penyelesaian KIA terhambat karena mendahulukan target E-KTP. Jumlah operator yang hanya satu orang harus menangani perakaman E-KTP dan KIA untuk satu kelurahan menyebabkan antrian untuk perakaman data E-KTP dan KIA seringkali tercampur dan simpangsiur yang menyebabkan waktu tunggu untuk pendataan menjadi sangat lama, bahkan seringkali masyarakat yang sudah menunggu dari pagi hingga siang terpaksa kembali keesokan harinya karena antrian yang begitu panjang.

Selain unsur manusia keberhasilan pelaksanaan kebijakan KIA juga harus didukung dengan adanya sarana dan prasarana yang memadai. Dalam hal prasarana adalah adanya dukungan koneksi dan jaringan internet antar kelurahan yang belum terintegrasi dengan baik ke server induk yang ada di kantor Kota Depok. Selain itu, ketersediaan sarana alat cetak, alat perekam, komputer hanya tersedia satu unit di tiap kelurahan dengan pemeliharaan yang tidak rutin setiap bulan. Seringkali peralatan rekam mengalami kerusakan, dan butuh waktu lebih dari satu minggu untuk perbaikan, dan selama perbaikan maka layanan perekaman data, baik KIA maupun E-KTP dihentikan.

Dengan sarana alat perekam dan alat pencetak yang sangat terbatas, menyebabkan munculnya antrian panjang di setiap kelurahan. Di Kelurahan Tugu Kecamatan Cimanggis misalnya, masyarakat yang hendak merekam KIA harus datang sejak subuh, karena jika mereka datang di atas jam sembilan pagi, bisa dipastikan mereka akan kehabisan nomor antrian. Bahkan setelah mendapatkan antrian, masyarakat harus menunggu dan bersabar untuk penyelesaian pelayanan EKTP maupun KIA yang diajukan, terlebih jika koneksi dengan server utama terjadi hambatan atau alat rekam yang seringkali mengalami kerusakan. 
Berkaitan dengan penyediaan sarana dan prasarana, secara faktual terlihat bahwa tidak tersedianya sarana dan prasarana yang diperlukan guna melaksanakan program-program baru akan menimbulkan berbagai hambatan terhadap keberhasilan pelaksanaan pencapaian tujuan yang telah ditetapkan. Sumber daya bukan hanya mencakup faktor sumber daya manusia / aparat semata melainkan juga mencakup kemampuan sumber daya material lainnya untuk mendukung pelaksanaan kebijakan tersebut. Oleh karena itu, maka keberhasilan implementasi kebijakan bukan hanya ditunjang oleh sumber daya manusia saja melainkan perlu ditunjang degan sarana dan prasarana yang memadai demi kelancaran penyelenggaraannya.

Persoalan lainnya adalah pendeknya masa berlaku KIA. Sejak awal diberlakukan, KIA hanya memiliki masa berlaku sepanjang dua tahun, dan secara otomatis tidak berlaku jika melewati masa berlaku dan/atau pemilik sudah berusia 17 tahun. Dengan masa berlaku yang terlalu pendek, menyebabkan masyarakat harus selalu ke kelurahan untuk memperpanjang KIA dan mengulang kembali proses pengajuan atau perpanjangan KIA yang sangat menyita waktu dan tenaga. Untuk menyelesaikan persoalan ini, Wali Kota Depok telah mengeluarkan Keputusan Wali Kota Depok Nomor 12/2017 yang memperpanjang masa berlaku KIA menjadi 4 tahun, namun pelaksanaannya baru dimulai pada awal 2019, itupun masih mundur di tingkat pelaksanaan karena ketersediaan blanko yang ada masih mencatat masa berlaku selama dua tahun.

C. Persoalan Komunikasi dengan Mitra KIA

Peran komunikasi dalam keberhasilan program Kartu Identitas Anak di Kota Depok sangat penting, karena dalam proses kebijakan publik yang menjadi salah satu kelemahannya adalah komunikasi, di mana seharusnya komunikasi dibangun sejak perencanaan kebijakan sehingga muatan-muatan atau materi yang akan menjadi inti dari kebijakan tersebut dapat diketahui dan disesuaikan dengan tuntutan kebutuhan dan perkembangan. Hal ini dapat dilihat pada pelaksanaan Kartu Identitas Anak terdapat beberapa persoalan komunikasi, baik antara Disdukcapil dengan dinas lain di Kota Depok, maupun antara Disdukcapil dengan Mitra KIA dan masyarakat umum.

Berkaitan dengan komunikasi dengan dinas lain, ada beberapa persoalan yang muncul, misalnya Disdukcapil Kota Depok seringkali mengadakan kegiatan yang berbeda namun dengan target audiens yang sama dengan dinas lain di waktu yang berdekatan dengan alasan ketidaktahuan bahwa dinas lain menyelenggarakan kegiatan yang relatif sama di daerah tersebut. Disdukcapil juga tidak secara langsung bekerjasama dengan Dinas Pendidikan atau Dinas Perlindungan Anak dan Pemberdayaan Masyarakat dan Keluarga, hal ini menyebabkan sosialisasi dan promosi program KIA tidak berjalan maksimal. Hal ini muncul disebabkan proses miskomunikasi dan birokrasi panjang yang harus dilalui oleh sebuah program untuk dapat berjalan, di samping bahwa setiap dinas seringkali memiliki programnya sendiri yang tidak sejalan dengan dinas lain. 
Dalam beberapa kesempatan, Dinas Pendidikan ketika mengadakan sosialisasi tentang Sekolah Ramah Anak (SRA) tidak menyertakan Disdukcapil untuk bicara soal KIA, padahal KIA dan SRA adalah bagian tidak terpisahkan dari ketercapaian program KLA. Pada kesempatan lain, Dinas Perlindungan Anak dan Pemberdayaan Masyarakat dan Keluarga ketika melalukan sosialisasi perlindungan perempuan dan anak di masyarakat, juga tidak menyertakan Disdukcapil, padahal salah satu fungsi KIA adalah pemenuhan hak sipil anak. Hal yang sama juga terjadi ketika Disdukcapil melakukan sosialisasi tentang Kartu Identitas Anak di lembaga pendidikan tidak melibatkan Dinas Pendidikan, atau ketika sosialisasi di masjid dan majelis taklim tidak melibatkan Dinas Sosial dan Keagamaan. Dalam beberapa kali wawancara, alasan mengapa tidak ada kerjasama antardinas terkait lebih pada persoalan birokrasi yang bertele-tele dan panjang, yang menyebabkan sebuah program kerjasama seringkali batal dilakukan.

Gejala miskomunikasi antardinas di Kota Depok terus berulang, dan meski Wali Kota Depok sudah memerintahkan agar dinas-dinas di Kota Depok menyelenggarakan kegiatan bersama, namun secara faktual di lapangan yang terjadi adalah tumpang-tindih kegiatan. Persoalan miskomunikasi antardinas di Kota Depok juga berdampak pada implementasi KIA di lapangan. Pendataan KIA misalnya, karena Disdukcapil tidak bekerjasama dengan Dinas Pendidikan, maka Disdukcapil tidak bisa melakukan perekaman data di sekolah, dengan demikian seluruh anak yang akan direkam datanya harus datang ke kelurahan, padahal kelurahan sendiri tidak siap dalam proses perakaman data karena tertumpuk dengan masyarakat yang akan mereka E-KTP. Contoh lainnya adalah untuk kebutuhan administrasi KIA yang melibatkan Dinas Kesehatan, seringkali Dinas Kesehatan tidak dapat mengeluarkan catatan kelahiran karena data perkawinan orangtua justru tertahan di Disdukcapil. Hal ini yang membuat orangtua yang ingin membuat KIA seringkali harus bolak-balik mengurus administrasi yang seringkali di-ping-pong dari satu dinas ke dinas lainnya.

Persoalan komunikasi krusial lainnya terjadi antara Disdukcapil dan Mitra KIA. Meskipun komunikasi yang ada antara Disdukcapil dan Mitra KIA sudah berjalan sejak 2017, belum ada progress berarti dalam pelaksanaannya. Sejak 2017 hingga medio 2019, Mitra KIA berjumlah 18 unit dan belum ada peningkatan. Hal ini dapat dilihat dari dua sisi. Pertama, Pemerintah Kota Depok tidak secara proaktif menjaring Mitra. Mitra KIA seringkali hanya sebatas diundang untuk mengikuti sosialisasi dan mengadakan MOU, yang hanya berdasarkan kesadaran untuk mendukung program Pemerintah Kota Depok dalam pelayanan administrasi kependudukan kepada anak. Dengan tidak adanya mekanisme yang mengatur kewajiban berbagai pihak seperti perbankan, toko buku, penyelenggara layanan kesehatan, dan penyelenggara layanan olahraga dan rekreasi untuk bergabung sebagai Mitra KIA, Mitra KIA yang ada saat ini adalah Mitra yang memang sejak awal memiliki jaringan dan kerjasama dengan Pemerintah Kota Depok. 
Kedua, Disdukcapil tidak dapat menjelaskan dengan baik keuntungan yang diperoleh Mitra KIA sehingga Mitra yang ada saat ini tidak secara aktif bergerak dalam pelaksanaan KIA di lapangan dan/atau tidak ada terobosan kerjasama, baik itu perluasan ruang lingkup kerjasama ataupun penambahan benefit bagi penerima KIA. Tidak hanya ketiadaan benefit bagi Mitra, berbagai aturan terkait kerjasama dengan Mitra pun tidak berjalan. Misalnya, berdasarkan kesepahaman antara Disdukcapil dan Mitra KIA, Mitra KIA diharuskan untuk memberikan informasi potongan harga bagi pemilik KIA, namun di lapangan, tidak ada informasi apapun terkait dengan hal tersebut. Contoh lainnya, terdapat aturan bahwa Mitra KIA harus memberikan laporan berkala setiap tiga bulan kepada Disdukcapil Kota Depok, namun dalam pelaksanaannya, tidak ada yang melakukan hal itu. Hampir semua Mitra KIA hanya memberikan laporan tahunan, beberapa Mitra bahkan belum pernah melaporkan target pencapaian dan penggunaan KIA ke Disdukcapil sejak 2017.

Hal ini disebabkan karena Diskdukcapil tidak memiliki mekanisme yang jelas mengenai pelaporan dan evaluasi program KIA oleh Mitra KIA. Terkait dengan pelaporan, tidak ada kejelasan tata cara pelaporan maupun laporan seperti apa yang diminta oleh Disdukcapil dari Mitra KIA. Tidak hanya ketidakjelasan cara dan jenis laporan, bahkan Disdukcapil tidak meminta laporan karena dalam Peraturan Wali Kota tidak jelas kapan dan bagaimana laporan harus dimintakan ke pihak Mitra. Di sisi lain, karena tidak ada kejelasan mengenai pelaporan, maka pihak Mitra KIA tidak bisa memberikan laporan sekaligus umpan balik sebagai evaluasi program KIA, sehingga Mitra KIA seringkali bertindak masa bodoh dengan pelaporan pelaksaan KIA, padahal Mitra KIA adalah stakeholder strategis pelaksanaan KIA di lapangan.

Karena mekanisme dan benefit KIA tidak diketahui dengan jelas oleh Mitra KIA, menyebabkan tidak ada satupun Mitra KIA yang memberikan informasi keuntungan KIA bagi masyarakat. Di toko buku yang menjadi Mitra KIA misalnya, kecuali pembeli menunjukkan KIA yang dimiliki, maka tidak ada potongan harga yang diberikan, bahkan jika yang dibeli adalah buku pelajaran yang sudah pasti digunakan oleh anak sekolah. Demikian pula perbankan, tidak ada satupun petunjuk ataupun mengenai manfaat KIA, terutama untuk anak yang berasal dari keluarga tidak mampu. Di fasilitas kesehatan pun sama, tidak ada satupun informasi mengenai KIA, bagaimana manfaat dan penggunaan KIA bagi pengguna layanan kesehatan. Hal ini menunjukkan bahwa Mitra KIA belum melihat KIA sebagai suatu keharusan untuk ditampilkan maupun program unggulan yang mampu memberikan manfaat balik bagi mereka, sehingga Mitra KIA cenderung diam dan tidak memberikan informasi manfaat KIA bagi pelanggan mereka.

Persoalan komunikasi juga terjadi antara Disdukcapil dengan masyarakat. Dengan jumlah personalia Disdukcapil yang sangat terbatas menyebabkan proses sosialisasi KIA di masyarakat menjadi sangat minim. Seringkali di kelurahan tidak dijelaskan apa manfaat KIA bagi pemiliknya, ditambah lagi tidak adanya petugas 
yang secara khusus ditugaskan untuk menjelaskan manfaat KIA, sehingga masyarakat hanya mengurus Akta Kelahiran dan perbaikan Kartu Keluarga tanpa mengurus KIA. Operator di kelurahan juga tidak meminta masyarakat untuk sekaligus merekam data KIA, dengan dalih bahwa tugas utama mereka adalah untuk fokus pada perekaman E-KTP.

Dalam sosialisasi di masyarakat luas, seringkali Disdukcapil lebih memfokuskan pada pembuatan Akta Kelahiran ketimbang KIA, hal ini dapat dilihat dari berbagai sosialisasi dan media sosialisasi yang dibagikan di beberapa tempat di Kota Depok, baik berupa reklame maupun pesan singkat layanan masyarakat. Sosialisasi KIA juga tidak terlihat di lembaga pendidikan, kecuali di beberapa sekolah yang memang sudah menjadi target dari sosialisasi KIA itu sendiri. Di tahun 2019, berdasarkan data Disdukcapil, hanya delapan belas sekolah yang menjadi lokasi sosialisasi KIA. Di luar sekolah-sekolah tersebut, KIA tidak tersosialisasikan dengan baik. Persoalan komunikasi KIA menjadi persoalan yang tidak pernah terselesaikan sejak awal KIA diluncurkan pada 2016, salah satu titik permasalahannya adalah tidak ada komunikasi yang lancer antardinas, antarmitra, dan dengan masyarakat. Sehingga tidak mengherankan, jika hingga hari ini KIA yang beredar di Kota Depok saat ini baru mencapai kurang dari tiga puluh persen dari total anak yang harus dipenuhi hak sipilnya.

\section{Kesimpulan}

Proses Penyusunan Kebijakan Kartu Identitas Anak di Kota Depok telah dilaksanakan oleh Disdukcapil Kota Depok yang direspon dengan positif oleh Walikota dan DPRD, kebijakan ini bertujuan untuk mensejahterakan anak-anak di Kota Depok. Untuk Formulasi Kebijakannya Pemerintah Kota Depok mendukung dan menyetujui usulan dari Disdukcapil memprioritaskan pelayanan administrasi kependudukan anak yang berkualitas sebagai salah satu program pendukung mewujudkan KLA. Kebijakan ini juga mendapatkan respon dari masyarakat dalam pembuatan KIA, karena masyarakat merasa bahwa dengan adanya KIA yang berfungsi sebagai identitas bagi anak juga sebagai fasilitas terhadap beberapa sektor di bidang pendidikan, kesehatan, pariwisata dan perbankan.

Implementasi kebijakan KIA berjalan relatif lancar meski selalu ada kendala pelaksanannya, baik dari sisi pelaksanaan KIA maupun Mita KIA. Dari sisi pelaksanaan, persoalan terletak pada tiga hal: Pertama, persyaratan pengajuan atau perpanjangan KIA yang sangat menyita waktu, terutama dalam proses persiapan dokumen yang dibutuhkan dalam pengajuan KIA. Kedua, persoalan ketersediaan operator dan perlengkapan perakaman data KIA di kelurahan yang masih menjadi satu dengan perekaman E-KTP menyebabkan perekaman data KIA sangat terhambat. Jumlah operator SIAK yang ada di masing-masing Kelurahan hanya satu orang sehingga bila operator berhalangan hadir maka pelayanan akan tertunda. Selain itu juga kenyataan dilapangan petugas SIAK lebih mengutamakan pembuatan E KTP yang merupakan program Nasional daripada KIA program lokal Kota Depok sehingga penyelesaian 
permohonan KIA masyarakat sering tertunda. Ketiga, karena terbatasnya personalia Disdukcapil menyebabkan sosialisasi yang dilakukan kurang merata karena dilaksanakan hanya kepada masyarakat yang ada di Kecamatan-Kecamatan belum menyeluruh sampai ke tingkat yang lebih rendah. Selain itu juga sosialisasi tidak dilakukan kepada anak-anak usia sekolah sehingga banyak dari mereka yang tidak mengetahui adanya KIA. Keempat, Kurang efektifnya masa berlaku KIA yang hanya 2 (dua) sehingga tidak menghemat anggaran belanja Pemerintah Kota Depok.

Dari sisi pemilik, KIA nampaknya belum memberikan potensi yang menguntungkan, hal ini dapat dilihat dari fasilitas yang didapat dengan KIA masih relatif sedikit karena belum maksimalnya keikutsertaan mitra pendukung yang memberikan fasilitas bagi anak-anak. Manfaat KIA tidak maksimal dilihat dari pengurangan harga (diskon) tidak bisa digabung antara KIA dan promo yang ada di Mitra Pendukung, sehingga masyarakat kurang merasakan manfaat KIA.

Tidak maksimalnya manfaat KIA dari sisi terbatasnya Mitra disebabkan bentuk kerjasama antara Pemerintah Kota Depok dengan Mitra pendukung sebatas menjalin kerjasama biasa yang cenderung non profit sehingga hanya mengandalkan kesadaran pihak Mitra pendukung untuk mendukung program pemerintah. Padahal disini diperlukan komitmen pemerintah yang bisa mempengaruhi keterlibatan Mitra KIA sehingga bisa memaksimalkan keterlibatan Mitra dalam pelaksanaan KIA.

Dalam pelaksanaan Peraturan Walikota Nomor 35/2015 tentang Kartu Identitas Anak di Kota Depok, terdapat beberapa rekomendasi yang diajukan, antara lain: meningkatkan sosialiasi KIA kepada masyarakat terutama anak usia sekolah yaitu melakukan kerjasama dengan Dinas Pendidikan Kota Depok dan sekolah sekolah baik negeri maupun swasta sehingga sasaran KIA pada usia anak sekolah dapat tercapai. Menambah jumlah operator SIAK masing-masing kelurahan sehingga apabila ada yang berhalangan hadir pelayanan akan tetap berjalan dan target dari masing-masing program Nasional yaitu EKTP, Akta Kelahiran dan KIA yang pelayanannya di Kelurahan dapat dicapai sesuai dengan standar ketentuan yang ada, dan menambah jumlah alat rekam dan alat cetak E KTP dan KIA di masing-masing kelurahan yang disesuaikan dengan jumlah penduduk.

Selain itu, penting pula untuk merevisi kembali Perjanjian dengan Mitra Kerja Pendukung untuk manfaat yang diberikan KIA kepada masyarakat sehingga masyarakat dapat lebih antusias menggunakan KIA dan merasakan manfaatnya. Dengan melakukan kajian ulang tentang substansi kerjasama dengan Mitra Kerja Pendukung supaya pihakpihak yang belum ikut serta sebagai Mitra Kerja Pendukung bisa tertarik untuk ikut serta mensukseskan Progam KIA di Kota Depok. Dengan terlibatnya berbagai pihak, maka KIA sebagai program yang memang sangat multistakeholder diharapkan mampu memenuhi hak sipil anak di Kota Depok, sehingga Depok layak mengklaim dirinya sebagai Kota Layak Anak. 


\section{BIBLIOGRAFI}

Adnyani, Ni Ketut Sari. (2019). Pelayanan Sektor Publik Terkait Pengaturan Administrasi Kependudukan Tentang Identitas Anak Dengan Pemberlakuan Permendagri Nomor 2 Tahun 2016. Jurnal Ilmiah Ilmu Sosial, 4(2), 200-203. https://doi.org/10.23887/jiis.v4i2.16536. Google Scholar

Arista, Windi Dwi, \& Suderana, Wayan. (2019). Implementasi Kebijakan Program Kartu Identitas Anak (Kia) Di Dinas Kependudukan Dan Catatan Sipil Kabupaten Badung. Jurnal Ilmiah Dinamika Sosial, 3(1), 56. https://doi.org/10.38043/jids.v3i1.1733 Google Scholar

Faedlulloh, Dodi, Prasetyanti, Retnayu, \& Indrawati. (2017). Menggagas Ruang Publik Berbasis Demokrasi Deliberatif: Studi Dinamika Pengelolaan Ruang Publik Terpadu Ramah Anak (RPTRA) di Jakarta Utara. Spirit Publik, 12(2), 43-60. Retrieved from www.news.detik.com, Google Scholar

Fitriani, R. (2016). Peranan Penyelenggara Perlindungan Anak Dalam Melindungi Dan Memenuhi Hak-Hak Anak. Jurnal Hukum Samudra Keadilan, 11(2), 250-358. Google Scholar

Haifulloh, Rizky, Purnomo, Eko Priyo, \& Salsabila, Lubna. (2020). Kehadiran Kartu Smart Madani dan Kartu Identitas Anak sebagai Program Pengembangan Smart City di Kota Pekanbaru. Gorontalo Journal of Government and Political Studies, 3(1), 038. https://doi.org/10.32662/gjgops.v3i1.825 Google Scholar

Hamudy, Moh. (2015). Upaya Mewujudkan Kota Layak Anak di Surakarta dan Makassar. Jurnal Bina Praja, 07(02), 149-160. https://doi.org/10.21787/jbp.07.2015.149-160 Google Scholar

Herlina, Netti, \& Nadiroh, Nadiroh. (2018). Peran Strategis Ruang Publik Terpadu Ramah Anak (Rptra) Dalam Rangka Pemenuhan Hak Anak Terhadap Lingkungan. JPUD - Jurnal Pendidikan Usia Dini, 12(1), 104-117. https://doi.org/10.21009//jpud.121.09 Google Scholar

Hernowo, Endy, \& Navastara, Ardy Maulidy. (2017). Karakteristik Ruang Publik Terpadu Ramah Anak (RPTRA) Bahari di Kecamatan Cilandak Jakarta Selatan. Jurnal Teknik ITS, 6(2), 4-7. https://doi.org/10.12962/j23373539.v6i2.25293 Google Scholar

Irenes, Maria Melcilin, \& Setiamandani, Emei Dwinanarhati. (2019). Pelayanan Publik Dalam Pembuatan Kartu Identitas Anak (KIA). Jurnal Ilmu Sosial Dan Ilmu Politik, 8(4), 272-277. Google Scholar

Iswariayti, Ida Ayu, Parsa, I. Wayan, \& Suardita, I. Ketut. (2016). Pelaksanaan Peraturan Menteri Dalam. 1-13. Google Scholar

Meru, Nawang. (2017). Implementation process of mayor regulation nomor 35 tahun 
2015 on kartu identitas anak (kia) in depok, west java province. Proceeding The 1st International Conference on Social Sciences, (39), 1-2. Google Scholar

Noer, Khaerul Umam. (2019). Mencegah Tindak Kekerasan pada Anak di Lembaga Pendidikan. Sawwa: Jurnal Studi Gender, 14(1), 47. https://doi.org/10.21580/sa.v14i1.2998 Google Scholar

Pasaribu, Ria Ratna Sari. (2018). Implementasi Kebijakan Dalam Pelayanan Pembuatan Kartu Identitas Anak (Kia) Di Dinas Kependudukan Dan Pencatatan Sipil Kota Batu. Jisip, 7(2), 158-162. Google Scholar

Patilima, H. (2017). Kabupaten Kota Layak Anak. Indonesian Journal of Criminology, 13(1), 229091. Google Scholar

Putri, Citra Kunia, \& Noor, trisna insan. (2013). Sosialisasi Program Kartu Identitas Anak Oleh Dinas Kependudukan Dan Pencatatan Sipil Di Kecamatan Langkaplancar Kabupaten Pangandaran. Jurnal Ilmiah Ilmu Administrasi Negara, 53(9), 1689-1699. Google Scholar

Roza, Darmini, \& S, Laurensius Arliman. (2018). Peran Pemerintah Daerah Untuk Mewujudkan Kota Layak Anak Di Indonesia. Jurnal Hukum Ius Quia Iustum, 25(1), 198-215. https://doi.org/10.20885/iustum.vol25.iss1.art10 Google Scholar

Setiawan, Hari Harjanto. (2017). Akte Kelahiran Sebagai Hak Identitas Diri Kewarganegaraan Anak. Sosio Informa, 3(1), 26-39. https://doi.org/10.33007/inf.v3i1.520 Google Scholar

Simamora, TJ, Bahmid, B., \& Martua, J. (2019). Status Anak Yang Mendapat Kartu Identitas Anak Berdasarkan Permendagri Nomor 2 Tahun 2016 Tentang Kartu Identitas Anak (Kia). Pengaturan Hukum Status Anak Yang Mendapat Kartu Identitas Anak Berdasarkan Permendagri Nomor 2 Tahun 2016 Tentang Kartu Identitas Anak (Kia), Vol. 1, No(1), 90-94. Retrieved from http://www.jurnal.una.ac.id/index.php/jt/article/view/983. Google Scholar

Sri Hardjanto, Untung. (2019). Kebijakan Penerbitan Kartu Identitas Anak di Kota Semarang. Administrative Law and Governance Journal, 2(2), 301-313. https://doi.org/10.14710/alj.v2i2.301-313 Google Scholar

Taliu, Sitti Ajeng Nurqarimah, \& Suranto, Suranto. (2020). Efektivitas Penerbitan KIA (Kartu Identitas Anak) Melalui Aplikasi Dukcapil Smart Kabupaten Bantul Tahun 2019. Jurnal Public Policy, 6(2), 90. https://doi.org/10.35308/jpp.v6i2.2421 Google Scholar

Taufiq, Rohmat, Hadikurniawati, Wiwien, Muhammadiyah, Universitas, \& Informatika, Teknik. (2019). Analisis dan Desain Sistem Informasi Pembuatan Kartu Identitas Anak (KIA) Pada Kecamatan Curug. Proceeding SINTAK 2019, 55-61. Google Scholar 
Asesmen Implementasi Kebijakan Kartu Identitas Anak Sebagai Pemenuhan Hak Anak

Widyawati, Karya, \& Laksmitasari, Rita. (2015). Penilaian Ruang Bermain Anak di Kota Depok Sebagai Satu Indikator Tercapainya Kota Layak Anak. Factor Exacta, 8(3), 195-207. Google Scholar

Yudha, Fernandes, \& Firdausi, Firman. (2017). Kualitas Pelayanan Publik Dalam Pembuatan Kartu Indentitas Anak ( KIA ). 6(2), 75-79. Google Scholar

\section{Copyright holder:}

Khaerul Umam Noer (2021)

First publication right:

Journal Syntax Literate

This article is licensed under:

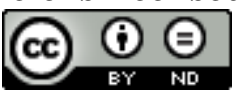

